\title{
STUDIES ON STORAGE BEHAVIOR OF SYRUP PREPARED FROM NAGPUR MANDARIN (CITRUS RETICULATE BLANCO)
}

\author{
ZAKI AHMAD FAIZI ${ }^{1}$, J. K. DHEMRE ${ }^{2}$, V. P. KAD ${ }^{3}$, A. M. MUSMADE ${ }^{4} \&$ M. B. SHETE ${ }^{5}$ \\ ${ }^{l}$ M.Sc. Foreign Student of Fruit Science, Post-Harvest Technology Centre, Department of Horticulture, Mahatma Phule Krishi \\ Vidyapeeth, Rahuri, Dist. Ahmednagar, Maharashtra, India \\ ${ }^{2}$ Assistant Professor of Horticulture, Post-Harvest Technology Centre, Department of Horticulture, Mahatma Phule Krishi \\ Vidyapeeth, Rahuri, Dist. Ahmednagar, Maharashtra, India \\ ${ }^{3}$ Assistant Professor of Agricultural Process Engineering, Post-Harvest Technology Centre, Department of Horticulture, Mahatma \\ Phule Krishi Vidyapeeth, Rahuri, Dist. Ahmednagar, Maharashtra, India \\ ${ }^{4}$ Professor of Horticulture, Post-Harvest Technology Centre, Department of Horticulture, Mahatma Phule Krishi Vidyapeeth, \\ Rahuri, Dist. Ahmednagar, Maharashtra, India \\ ${ }^{5}$ Associate Professor of Horticulture, Post-Harvest Technology Centre, Department of Horticulture, Mahatma Phule Krishi
} Vidyapeeth, Rahuri, Dist. Ahmednagar, Maharashtra, India

\begin{abstract}
The storage behavior of syrup prepared from mandarin orange juice having 55oB TSS using different preservative levels (150, 250 and 350 ppm sodium benzoate) packed with different packaging materials (glass bottles and PET bottles) and stored at ambient (19.80-27.60oC and 43.00-70.60\% R.H.) and cold storage (5 $\pm 20 \mathrm{C}$ and $92-95 \%$ R.H.) was studied. The data regarding chemical composition of syrup revealed that, there was an increase in TSS, acidity, total sugars, reducing sugars while $\mathrm{pH}$ and ascorbic acid decreased in all treatments of syrup during 180 days of storage. During sensory evaluation, decrease was observed in color, flavor, taste, overall acceptability of syrup during 180 days of storage. The microbial quality viz. Yeast and mold count of syrup were found to be increased during 180 days of storage. The microbial growth was observed within acceptable level in all treatments of syrup. The treatment combination of syrup T11 (S2P3B1, syrup prepared with 350 ppm preservative levels packed in glass bottles and stored in cold storage) followed by T12 (S2P3B2, syrup prepared with 350 ppm preservative levels packed in PET bottles and stored in cold storage) based on chemical composition, sensory evolution and microbial quality was found to be superior as compared to other treatments. Nagpur mandarin syrup of $55^{\circ} B$ could be stored for 180 days in a glass bottle in cold storage $\left(5 \pm 2^{\circ} \mathrm{C}\right)$ by using $350 \mathrm{ppm}$ sodium benzoate as preservative. The cost economics of prepared syrup were observed to be Rs. 55.02 per liter.

KEYWORDS: Nagpur Mandarin, Syrup, Sodium Benzoate, Packaging Materials, Storage, Sensory, Chemical Composition, Yeast and Mold Count \& Cost of Preparation
\end{abstract}

Received: May 05, 2017; Accepted: Jun 03, 2017; Published: Jun 28, 2017; Paper Id.: IJASRAUG201710

\section{INTRODUCTION}

Mandarin orange (Citrus reticulate Blanco) is one of the most popular citrus fruit having attractive bright color, appealing taste and flavor. Citrus is grown in 114 countries around the world. Out of these, 53 countries grow citrus commercially with a total production of more than 115 million tonnes. On production basis, China tops the list with 22.9 million tonnes, followed by Brazil with 22.7 million tonnes and USA with 10.4 million tones. India with 10.48 million tonnes is in 4th position (Anonymous, 2015). At present mandarin cultivation has assumed great 
importance among north Indian growers and a large acreage of land is being brought under cultivation, particularly in Punjab, Madhya Pradesh, Andhra Pradesh, Maharashtra, Rajasthan, Assam and Karnataka. Total mandarin production in India is 3.70 million tones with 0.31 million ha area and 9.3 tons/ ha as productivity (Ladaniya, 2015). In Maharashtra, mandarin is grown in an area of 1.35 lakh ha area with the production of 7.425 lakh MT with the productivity of 5.5 MT per hectares (Anonymous, 2015 a). Citrus fruits have numerous therapeutic properties like anticancer, anti-tumor and antiinflammatory reported by Etebu et al. (2014). These properties are due to the photon- vitamins and nutrients present in the citrus fruits. Aslin (2014) Nagpur Santra is the most important commercial cultivar of India. This cultivar is considered to be one of the finest mandarins in the world. Its cultivation is concentrated mainly in the Nagpur region of central India. The fruit is large in size and mild, pleasant and aromatic flavor. Abundant juice, 4 to 11 seeds, poly embryonic, quality deteriorates if stored or kept on the tree after ripening (Chattopadhyay, 2007). Presently 95 per cent of the production goes for the fresh fruit market. It is notable that due to poor post-harvest infrastructure, wastage of mandarin is around 25-30 per cent and that only 5 per cent of the total production is processed presently (Anonymous. 2015b). A research work was therefore undertaken to study the storage behavior of Nagpur mandarin syrup and their cost economics.

\section{MATERIALS AND METHODS}

\section{Nagpur Mandarin Fruits}

Fully ripened, mature, fresh and sound fruits were purchased from orange orchard located in Ahmednagar district of Maharashtra for preparation of syrup and the materials such as citric acid, sodium benzoate were also purchased from local markets. Fruit was washed in tap water and then were peeled and used as experimental materials in the following procedure.

\section{Syrup Preparation}

The juice was extracted by using screw type pulper and used for preparation of syrup. Sugar syrup was prepared by addition of water in sugar to boiling at a temperature of $90{ }^{\circ} \mathrm{C}$, then the sugar syrup temperature decreased up to $60{ }^{0} \mathrm{C}$ and juice was mixed well with it. The syrup was bottled in the pre-sterilized $200 \mathrm{~mL}$ transparent glass bottles and PET bottles and sealed. After bottling, all syrup samples were sterilized for $20 \mathrm{~min}$. The prepared syrup was stored at ambient (19.80-27.60 ${ }^{\circ} \mathrm{C}$ and $43.00-70.60 \%$ R.H.) and cold $\left(5 \pm 2{ }^{\circ} \mathrm{C}\right.$ and $92-95 \%$ R.H.) storage. The treatment details are given in Table 1. The syrup samples were evaluated at an interval of 30 days up to 6 months for Physio-chemical analysis, sensory evaluation and microbial count. The process flow chart for preparation of syrup was shown in Figure 1.

\section{Observations were Recorded}

\section{Physical Parameters of Fresh Mandarin Fruit}

The physical parameters such as fruit weight $(\mathrm{g})$, peel weight $(\mathrm{g})$, seed weight $(\mathrm{g})$, juice weight $(\mathrm{g})$, pomace weight $(\mathrm{g})$, peel thickness $(\mathrm{cm})$, fruit length $(\mathrm{cm})$, fruit breadth $(\mathrm{cm})$ and Segment $(\mathrm{pcs})$ were recorded.

\section{Chemical Analysis}

The chemical parameters such as TSS, titratable acidity, $\mathrm{pH}$, ascorbic acid (vitamin $\mathrm{C}$ ), total sugars, and reducing sugars was determined by the standard method as suggested by A.O.A.C. (1990) and Ranganna (2005).

\section{Sensory Evaluation}

For assessing sensory quality attributes, organoleptic evaluation was carried by a panel of 8-10 judges by using 9- 
point hedonic scale as given by Amerine et al. (1979) and Ranganna (2005).

\section{Microbial Quality}

The microbial (yeast and mold) analysis of Nagpur mandarin syrup was carried out by taking $1 \mathrm{~mL}$ of each of the sample and add to $9 \mathrm{ml}$ of sterilized distilled water, serial dilution were done on all samples $\left(10^{-6}\right)$. $1 \mathrm{~mL}$ of each from appropriate dilution was plated on required medium (PDA) and then incubation was carried out. In each count, after incubation, the average count of colonies present on Petri plates were multiplied by dilution factor and expressed as CFU (colony forming unit) /ml of sample (Adedeji and Oluwana, 2013).

\section{- Statistical Analysis}

The experiments were planned and carried out using Factorial Completely Randomized Design (FCRD) with three replications. The data obtained in the present investigation from chemical composition and sensory parameters were analyzed for the statistical significance according to the procedure given by Panse and Sukhatme (1985).

\section{RESULTS AND DISCUSSIONS}

\section{Physic-Chemical Composition of Fresh Nagpur Mandarin Fruit}

The results for physical-chemical composition of fresh mandarin orange fruit CV. Nagpur mandarin is presented in Table 2. The data revealed that the fresh Nagpur mandarin had $128.8 \mathrm{~g}$ fruit weight, $19.59 \mathrm{~g}$ peel weight (15.21\%), 3.10 $\mathrm{g}$ seed weight (2.41\%), $68.39 \mathrm{~g}$ juice weight (53.09\%), 37.72g pomace weight $(29.29 \%), 0.24 \mathrm{~cm}$ peel thickness, $5.6 \mathrm{~cm}$ fruit length, $6.21 \mathrm{~cm}$ fruit breath, 11 pieces of segments, $10.72^{0} \mathrm{~B}$ total soluble solids, 0.621 percent acidity, $3.89 \mathrm{pH}$, $43.46 \mathrm{mg} / 100 \mathrm{ml}$ ascorbic acid, 9.68 per cent total sugars and 3.89 per cent reducing sugars, respectively. Similar results were also recorded by Kumar (2009) and Verma et. al., (2012) in Nagpur mandarin

\section{Chemical Composition of Nagpur Mandarin Syrup during Storage}

The data for changes in chemical composition of Nagpur mandarin syrup subjected to different packaging materials, preservative levels and storage conditions are given and discussed below.

\section{Total Soluble Solids (T.S.S.) $\left({ }^{\circ} \mathbf{B}\right)$}

The TSS content of Nagpur mandarin syrup was found to be statistically significant up to 60 days of storage afterward it was observed non-significant. The minimum increase in TSS of syrup was found in high preservative level when packed in glass bottle and stored in cold storage. The minimum TSS was recorded in S2P3B1 (56.850 to 58.080 $\left.{ }^{\circ} \mathrm{B}\right)$ followed by S2P3B2 (56.850 to $\left.58.200{ }^{\circ} \mathrm{B}\right)$, while the maximum TSS was recorded in S1P1B2 (56.850 to $\left.59.010{ }^{\circ} \mathrm{B}\right)$ followed by S1P1B1 (56.850 to $58.970{ }^{\circ} \mathrm{B}$ ) during 180 days of storage period (Table 3$)$. The TSS content increased during the storage period in syrup might be due to reduction of moisture content by evaporation of water, conversion of insoluble carbohydrates into soluble sugars and hydrolysis of polysaccharides into monosaccharide and oligosaccharides during storage. The results are in agreement with the research work carried out by Das (2009) on jamun RTS, nectar, squash and syrup and Mandal et al. (2014) in aonla syrup.

\section{Acidity (\%)}

The acidity of Nagpur mandarin syrup was found to be statistically non-significant. The minimum increase in acidity of syrup was found in high preservative level packed in glass bottle and stored in cold storage. The minimum 
acidity was recorded in S2P3B1 (from 0.930 to $1.081 \%$ ) followed by S2P3B2 (from 0.930 to $1.088 \%$ ), while the maximum acidity was recorded in S1P1B2 (from 0.930 to $1.137 \%$ ) followed by S1P1B1 (from 0.930 to $1.133 \%$ ) during 180 days of storage period (Table 3). The acidity increased during 180 days of storage period might be due to decrease in $\mathrm{pH}$, degradation of pectic substances into soluble solids and release of acid from juice particles. The results are in agreement with the research work carried out by Das (2009) in RTS, nectar, squash and syrup prepared from jamun and Mandal et al. (2014) in aonla syrup

pH

The $\mathrm{pH}$ content of Nagpur mandarin syrup was found to be statistically non-significant. The minimum decrease in $\mathrm{pH}$ of syrup was found in high preservative level packed in glass bottle and stored in cold storage. The maximum $\mathrm{pH}$ was recorded in S2P3B1 (from 3.170 to 2.390) followed by S2P3B2 (from 3.170 to 2.360), while the minimum pH was recorded in S1P1B2 (from 3.170 to 1.940) followed by S1P1B1 (from 3.170 to 1.957) during 180 days of storage period (Table 3). The $\mathrm{pH}$ content was decreased during the advancement of storage period. The decrease in value of $\mathrm{pH}$ occurs due to degradation of pectin substances, formation of acidic compounds by degradation of reducing sugars, variation in composition of beverage and accumulation of organic acid would make the $\mathrm{pH}$ value drop during fermentation. The results are in agreement with the research work carried out by Chatha et al. (2008) on mandarin beverages.

\section{Ascorbic Acid (mg per $100 \mathrm{~mL})$}

The ascorbic acid content of Nagpur mandarin syrup was found to be statistically significant upto 150 days of storage from 150 upto end of storage period (180 days) was recorded non-significant. The minimum decrease in ascorbic acid of syrup was found in high preservative level packed in glass bottle and stored in cold storage. The maximum ascorbic acid was recorded in S2P3B1 from 16.80 to $11.38 \mathrm{mg} / 100 \mathrm{~mL}$ followed by S2P3B2 from 16.80 to $10.82 \mathrm{mg} / 100 \mathrm{~mL}$, while the minimum ascorbic acid was recorded in S1P1B2 from 16.80 to $6.08 \mathrm{mg} / 100 \mathrm{~mL}$ followed by S1P1B1from 16.80 to 7.09 $\mathrm{mg} / 100 \mathrm{~mL}$ during 180 days of storage period (Table 3). The ascorbic acid content during 180 days of storage was found to be decreased, which might be due to oxidation of ascorbic acid, oxidation of ascorbic acid by enzymes and various treatments applied, conversion of L-ascorbic acid into dihydro ascorbic acid oxidase (ascorbinase) because of heat processing and the presence of air in the head space of packaging materials. Similar results were also reported Das (2009) in RTS, nectar, squash and syrup of jamun.

\section{Total Sugars $(\%)$}

The total sugar content of Nagpur mandarin syrup was found to be statistically non-significant. The minimum increase in total sugars of syrup was found in high preservative level packed in glass bottle and stored in cold storage. The minimum total sugars were recorded in S2P3B1 from 47.82 to 49.500 per cent, followed by S2P3B2 from 47.82 to 49.513 per cent, while the maximum total sugars were recorded in S1P1B2 from 47.82 to 49.907 per cent, followed by S1P1B1from 47.82 to 49.857 per cent during 180 days of storage period (Table 3). The total sugars during 180 days of storage period were found to be increased which might be due to loss of moisture or due to conversion of starch and carbohydrates into sugars, hydrolysis of polysaccharides (like pectin, cellulose and starch) into monosaccharide and oligosaccharides, inactivation of enzymes which are responsible for decreasing acidity and the conversion of polysaccharides into simple sugars. The results are in agreement with the research work carried out by Mandal et al. (2014) on aonla syrup. 


\section{Reducing Sugars (\%)}

The reducing sugars of Nagpur mandarin syrup were found to be statistically non-significant. The minimum increase in reducing sugars of syrup was found in high preservative level packed in glass bottle and stored in cold storage. The minimum, reducing sugars was recorded in S2P3B1 from 21.31 to 21.840 per cent, followed by S2P3B2 from 21.31 to 21.863 per cent, while the maximum reducing sugars was recorded in S1P1B2 from 21.31 to 22.280 per cent, followed by S1P1B1 from 21.31 to 22.226 per cent during 180 days of storage period (Table 3). The data revealed that, there was increase in reducing sugar content during 180 days' storage. During storage, the reducing sugars were increased which might be due to hydrolysis of non-reducing sugars to reducing sugars, inversion process of sucrose to glucose and fructose by the acid, gradual inversion of non-reducing sugars and acids into reducing sugars in acidic medium, in heat processed juices during storage might be due to the inactivation of enzymes, which might play an important part in the reactions responsible for decreasing acidity and conversion of polysaccharides into simple sugars. The results are in agreement with the research work carried out by Mandal et al. (2014) on aonla syrup.

\section{Sensory Evaluation of Nagpur Mandarin Syrup during Storage}

\section{Colour}

The color of Nagpur mandarin syrup was found to be statistically non-significant up to 90 days of storage afterward it was observed significant. The minimum decrease in color of syrup was found in high preservative level when packed in glass bottle and stored in cold storage. The maximum color scores were recorded in S2P3B1 from 7.19 to 6.92 followed by S2P3B2 from7.13 to 6.85, while the minimum color scores were recorded in S1P1B2 from 5.96 to 5.09 followed by S1P1B1 from 6.11 to 5.18 during 180 days of storage (Table 4). The data indicates that the scores for colour decreased continuously during 180 days of storage. This might be due to non-enzymatic reaction of organic acid with sugars or oxidation of phenols, which leads to the formation of brown pigments. Similar results were also observed by Chatha et al. (2008) on color of mandarin beverage.

\section{Flavour}

The flavor of Nagpur mandarin syrup was found to be statistically non-significant up to 60 day of storage afterward it was observed statistically significant. The minimum decrease in flavour of syrup was found in high preservative level packed in glass bottle and stored in cold storage. The maximum flavour scores were recorded in S2P3B1 from 8.17 to 7.61 followed by S2P3B2 from 8.11 to 7.54 , while the minimum flavour scores were recorded in S1P1B2 from 6.94 to 5.78 followed by S1P1B1from 7.09 to 5.87 during 180 days of storage period (Table 4). The score of flavour in all treatments were decreased with increase of storage period which might be due to temperature which reduced the orange like flavour and increased the presence of off-flavors. The similar results were also observed by Chatha et al. (2008) on flavour of mandarin beverage.

\section{Taste}

The taste of Nagpur mandarin syrup was found to be statistically non-significant up to 60 day of storage afterward significant. The minimum decrease in taste of syrup was found in high preservative level packed in glass bottle and stored in cold storage. The maximum taste scores were recorded in S2P3B1 from 8.19 to 7.68 followed by S2P3B2 from 8.13 to 7.61, while the minimum taste scores were recorded in S1P1B2 from 6.86 to 5.85 followed by S1P1B1from 6.94 to 5.94 during 180 days of storage period (Table 4). From the data, it was observed that the taste scores were decreased gradually 
during 180 days of storage. The gradual loss in taste scores over the entire storage period was due to changes in volatile compounds of beverages. The similar results were also observed by Perez et al. (2005) on taste of mandarin; Chatha et al. (2008) on taste of mandarin beverage.

\section{Overall Acceptability}

The overall acceptability of Nagpur mandarin syrup was found to be statistically non-significant up to 30 day of storage afterward found to be significant. The minimum decrease in overall acceptability of syrup was found in high preservative level packed in glass bottle and stored in cold storage. The maximum overall acceptability scores were recorded in S2P3B1 from 7.85 to 7.40 followed by S2P3B2 from 7.79 to 7.33 , while the minimum overall acceptability scores were recorded in S1P1B2 from 6.59 to 5.57followed by S1P1B1 from 6.71 to 5.66 during 180 days of storage (Table 4). The data on changes in overall acceptability score observed that all the treatments had decreasing trend during 180 days which might be due to oxidation, storage time, temperature, oxygen content, light exposure, packaging materials sorption or chemical contamination and changes in volatile compounds of beverages. The similar results were also observed by Perez et al. (2005) in mandarin; Chatha et al. (2008) in mandarin beverage.

\section{Microbial Quality (Yeast and Mould) of Nagpur Mandarin Syrup}

The data presented in Table 5 revealed that, the microbial detection was negligible and within acceptable level (less than 2.00 colony forming unit per $\mathrm{mL}$ ) in all treatment combinations at ambient storage upto 180 days in syrup. The microbial detection was negligible and within acceptable level in all treatment combinations at cold storage upto 180 days in syrup. The microbial growth was found to be within acceptable level in the syrup which might be due to acid environment, chemical preservative, packaging materials, high sugar level maintained the syrup at a safe level and has prevented microbial growth. Similar results reported by Covadonga et al. (2002) on orange juice; Himani (2003) on kinnow mandarin juice.

\section{Cost of Preparation of Nagpur Mandarin Syrup}

It could be observed from the Table 6 that the cost of preparation of syrup prepared from Nagpur mandarin fruits was found to be Rs. 55.02 per litre

\section{SUMMARY AND CONCLUSIONS}

The data regarding chemical composition revealed that, there was increase in TSS, acidity, total sugars, reducing sugars while $\mathrm{pH}$ and ascorbic acid decreased in all treatments of syrup during 180 days of storage. During sensory evaluation decrease was observed in colour, flavour, taste, overall acceptability of syrup during 180 days of storage. The microbial quality viz. yeast and mould count of syrup were found to be increased during 180 days of storage. The microbial growth was observed within acceptable level in all treatments of syrup. The treatment combination of syrup T11 (S2P3B1) followed by T12 (S2P3B2) based on chemical composition, sensory evolution and microbial quality was found to be superior as compared to other treatments. The cost of preparation of 1 liter syrup from Nagpur mandarin fruits was found to be Rs. 55.02 for best treatment combination of S2P3B1 i.e. cold storage+350 ppm preservative level+ glass bottle. 


\section{REFERENCES}

1. A.O.A.C. (1990). Official methods of analysis 15th edition. Association of Analytical Chemists. Washington. D.C. 2004.

2. Amerine, M. A., Pangborn, R. M. and Roesseler, E. B. (1979). Principles of sensory evaluation of food. Academic press, New York., pp. 349-397.

3. Anonymous. (2015). Indian Horticulture Database 2014. National Horticulture Board, Ministry of Agriculture, Government of India, Gurgaon, INDIA. pp. 2-3.

4. Adedeji, T. O. and Oluwalana, I. B. (2013). Physic-chemical, sensory and microbial analysis of wine produced from watermelon (Citrullus Lanatus) and pawpaw (Carica papaya) blend. Food Science and Quality Management, 19: 2224-6088

5. Aslin S. A. (2014). Role of Citrus fruits in health. J. Pharm. Sci. \& Res., 6(2): 121-123.

6. Chattopadyay. T. K. (2007). A text book on pomology subtropical fruits, 3(2): 16.

7. Chatha Z. A., Mubeen Ahmed, Asif Ahmad and Syed Muhammad Raihan Dilshad. (2008). Studies on preparation of ready to serve mandarin (Citrus reticulata) diet drink. Pak. J. Agri. Sci., 45(4): 470-476.

8. Covadonga, R. A., Jacqueline K. B., Lorrie M. F., Renee M. G., and Mickey E. P. (2002). Yeast species associated with orange juice: Evaluation of different identification methods. Applied and environmental microbiology, 68(4):1955-1961.

9. Das, J. N. (2009). Studies on storage stability of jamun beverages. Indian J. Hort., 66(4): 508-510.

10. Etebu, E., Nwauzoma, A. B. (2014). A review on sweet orange (Citrus sinensis Osbeck): health, diseases, and management. American Journal of Research Communication, 2(2): 33-70.

11. Himani, K. (2003). Studies on processing of kinnow juice extracted via modified method of bitterness kinnow juice extraction. M.Sc. Biotechnology thesis, Patiala university, Punjab, India.

12. Kumar, R. (2009). Post-harvest profile of mandarin. Government of India, Department of Agriculture and Corporation, Directorate of Marketing and Inspection, Nagpur branch. pp 1-74.

13. Ladaniya, M. S. (2015). Citrus industry in India: Challenges and Prospects. In ICAR-Sponsored winter school on "precision citriculture for sustainable production and post harvest management", pp.1-10.

14. Mandal, P. and Sahoo, B. B. (2014). Studies on processing and storage stability of aonla (Emblica officinais Gaertn) syrup for nutritional security. Indian Horticulture Journal, 4(1): 49-51.

15. Panse, V. G. and Sukhatme, P. V. (1985). Statistical methods of agricultural workers, ICAR, New Delhi, pp. 143-147.

16. Perez, A. G., Pillar Luaces, Jesus Oliva, Jose J. Rlos, Carlos Sanz. (2005). Changes in vitamin C and flavour components of mandarin juice due to curing of fruits. Food Chemistry, (91): 19-24.

17. Ranganna, S. (2005). Handbook of analysis and quality control for fruits and vegetable products. 2nd Edn. Tata McGraw Hill. Publ. Co., Ltd., New Delhi, India.

18. Verma, S., Prerak, B. and Aruna, Y. (2012). Physic-chemical, yield and yield attributing characteristics of Nagpur mandarin orchard surveyed in Jhalawar District of Rajasthan. Asian Journal of Horticulture, (2): 237- 441. 


\section{APPENDICES}

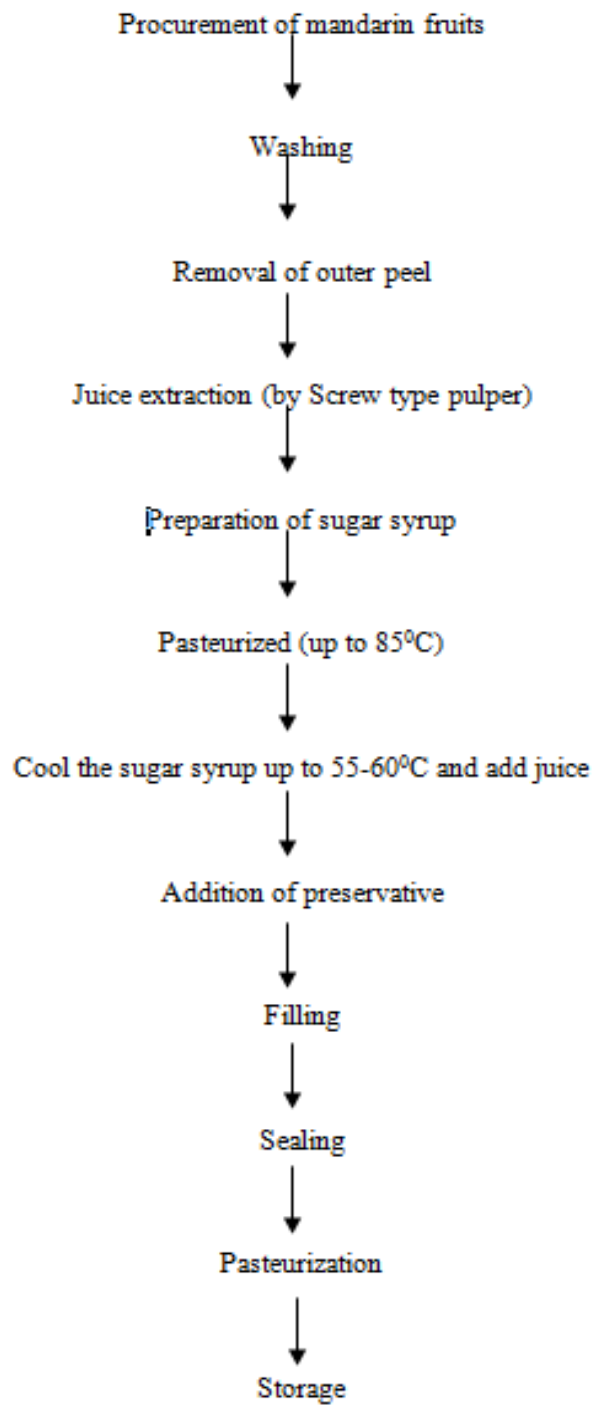

Figure 1: Flow Process Chart for Preparation of Syrup

Table 1: Treatments Details

\begin{tabular}{|c|c|c|}
\hline T. NO & \multicolumn{3}{|c|}{ Treatment Combinations } \\
\hline TI & S1P1B1 & Room Storage + 150ppm Sodium Benzoate + Glass Bottle. \\
\hline T2 & S1P1B2 & Room Storage + 150ppm Sodium Benzoate + Pet Bottle. \\
\hline T3 & S1P2B1 & Room Storage + 250ppm Sodium Benzoate + Glass Bottle \\
\hline T4 & S1P2B2 & Room Storage + 250ppm Sodium Benzoate + Pet Bottle \\
\hline T5 & S1P3B1 & Room Storage + 350ppm Sodium Benzoate + Glass Bottle. \\
\hline T6 & S1P3B2 & Room Storage + 350ppm Sodium Benzoate + Pet Bottle. \\
\hline T7 & S2P1B1 & Cold Storage + 150ppm Sodium Benzoate + Glass Bottle. \\
\hline T8 & S2P1B2 & Cold Storage + 150ppm Sodium Benzoate + Pet Bottle. \\
\hline T9 & S2P2B1 & Cold Storage + 250ppm Sodium Benzoate + Glass Bottle \\
\hline T10 & S2P2B2 & Cold Storage + 250ppm Sodium Benzoate + Pet Bottle \\
\hline T11 & S2P3B1 & Cold Storage + 350ppm Sodium Benzoate + Glass Bottle. \\
\hline T12 & S2P3B2 & Cold Storage + 350ppm Sodium Benzoate + Pet Bottle. \\
\hline
\end{tabular}


Table 2: Physic-chemical Characteristics of Nagpur Mandarin Fruit (Average of 30 Fruit)

\begin{tabular}{|c|l|l|}
\hline S. no & \multicolumn{1}{|c|}{ Parameters } & \multicolumn{1}{c|}{ Contents } \\
\hline 1 & Fruit wt. ( g ) & $128.8(100 \%)$ \\
\hline 2 & Peel wt. ( g ) & $19.59(15.21 \%)$ \\
\hline 3 & Seed wt. ( g ) & $3.10(2.41 \%)$ \\
\hline 4 & Juice wt. ( g ) & $68.39(53.09 \%)$ \\
\hline 5 & Pomace wt. ( g ) & $37.72(29.29 \%)$ \\
\hline 6 & peel thickness ( cm ) & 0.24 \\
\hline 7 & fruit length ( cm ) & 5.60 \\
\hline 8 & fruit breadth ( cm ) & 6.21 \\
\hline 9 & Segment ( pcs ) & 11.00 \\
\hline 10 & T.S.S. ( $\left.{ }^{0} \mathrm{~B}\right)$ & 10.72 \\
\hline 11 & Acidity ( \% ) & 0.621 \\
\hline 12 & pH & 3.89 \\
\hline 13 & Ascorbic Acid ( mg/100 ml ) & 43.46 \\
\hline 14 & Total Sugars ( \% ) & 9.68 \\
\hline 15 & Reducing Sugars ( \% ) & 3.89 \\
\hline
\end{tabular}

Table 3: Chemical Composition of Nagpur Mandarin Syrup during 180 Days of Storage

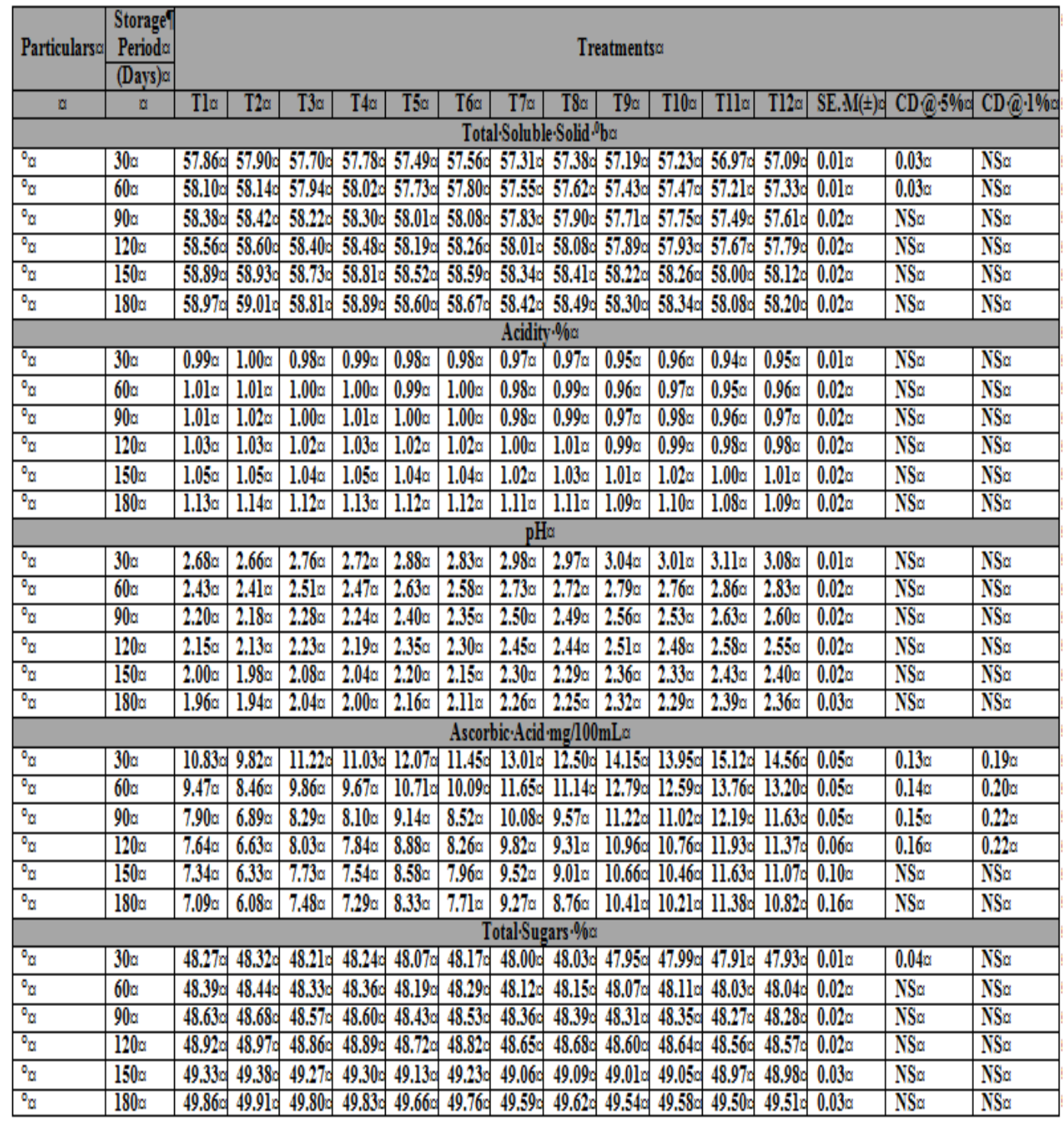


Table 4: Sensory Parameters of Nagpur Mandarin Syrup during 180 Days of Storage

\begin{tabular}{|c|c|c|c|c|c|c|c|c|c|c|c|c|c|c|c|c|}
\hline \multirow[t]{3}{*}{ Particulars } & $\begin{array}{l}\text { Storage } \\
\text { Period }\end{array}$ & & & & & & & & & & & & & & & \\
\hline & (Days) & \multicolumn{15}{|c|}{ Treatments } \\
\hline & & T1 & $\mathrm{T2}$ & T3 & T4 & T5 & T6 & T7 & T8 & T9 & T10 & T11 & T12 & SE. M( $( \pm)$ & CD@5\% & CD@1\% \\
\hline \multicolumn{17}{|c|}{ Color } \\
\hline & 0 & 6.11 & 5.96 & 6.58 & 6.37 & 6.9 & 6.87 & 6.97 & 6.95 & 7.08 & 7.02 & 7.19 & 7.13 & 0.4734 & NS & NS \\
\hline & 30 & 5.39 & 5.3 & 5.53 & 5.51 & 5.78 & 5.57 & 6.26 & 6.13 & 6.98 & 6.85 & 7.13 & 7.06 & 0.1501 & NS & NS \\
\hline & 60 & 5.36 & 5.27 & 5.5 & 5.48 & 5.75 & 5.54 & 6.23 & 6.1 & 6.95 & 6.82 & 7.1 & 7.03 & 0.0566 & NS & NS \\
\hline & 90 & 5.32 & 5.23 & 5.46 & 5.44 & 5.71 & 5.5 & 6.19 & 6.06 & 6.91 & 6.78 & 7.06 & 6.99 & 0.0416 & NS & NS \\
\hline & 120 & 5.24 & 5.15 & 5.38 & 5.36 & 5.63 & 5.42 & 6.11 & 5.98 & 6.83 & 6.7 & 6.98 & 6.91 & 0.0127 & 0.0357 & 0.0502 \\
\hline & 150 & 5.21 & 5.12 & 5.35 & 5.33 & 5.6 & 5.39 & 6.08 & 5.95 & 6.8 & 6.67 & 6.95 & 6.88 & 0.0104 & 0.0292 & 0.0411 \\
\hline & 180 & 5.18 & 5.09 & 5.32 & 5.3 & $\mathbf{5 . 5 7}$ & 5.36 & 6.05 & 5.92 & 6.77 & 6.64 & 6.92 & 6.85 & 0.0069 & 0.0195 & 0.0274 \\
\hline \multicolumn{17}{|c|}{ Flavor } \\
\hline & 0 & 7.09 & 6.94 & 7.56 & 7.35 & 7.88 & 7.85 & 7.95 & 7.93 & 8.06 & 8 & 8.17 & 8.11 & 0.4157 & NS & NS \\
\hline & 30 & 6.34 & 6.25 & 6.48 & 6.46 & 6.73 & 6.52 & 7.21 & 7.08 & 7.93 & 7.8 & 8.08 & 8.01 & 0.0924 & NS & NS \\
\hline & 60 & 6.26 & 6.17 & 6.4 & 6.38 & 6.65 & 6.44 & 7.13 & 7 & 7.85 & 7.72 & 8 & 7.93 & 0.0531 & NS & NS \\
\hline & 90 & 6.15 & 6.06 & 6.29 & 6.27 & 6.54 & 6.33 & 7.02 & 6.89 & 7.74 & 7.61 & 7.89 & 7.82 & 0.0208 & 0.0584 & 0.0822 \\
\hline & 120 & 6.11 & 6.02 & 6.25 & 6.23 & 6.5 & 6.29 & 6.98 & 6.85 & 7.7 & 7.57 & 7.85 & 7.78 & 0.0121 & 0.0341 & 0.048 \\
\hline & 150 & 6.01 & 5.92 & 6.15 & 6.13 & 6.4 & 6.19 & 6.88 & 6.75 & 7.6 & 7.47 & 7.75 & 7.68 & 0.0092 & 0.026 & 0.0365 \\
\hline & 180 & 5.87 & 5.78 & 6.01 & 5.99 & 6.26 & 6.05 & 6.74 & 6.61 & 7.46 & 7.33 & 7.61 & 7.54 & 0.0058 & 0.0162 & 0.0228 \\
\hline \multicolumn{17}{|c|}{ Taste } \\
\hline & 0 & 6.94 & 6.86 & 7.58 & 7.34 & 7.9 & 7.87 & 7.97 & 7.95 & 8.08 & 8.02 & 8.19 & 8.13 & 0.2483 & NS & NS \\
\hline & 30 & 6.38 & 6.29 & 6.52 & 6.5 & 6.77 & 6.56 & 7.25 & 7.12 & 7.97 & 7.84 & 8.12 & 8.05 & 0.0566 & NS & NS \\
\hline & 60 & 6.29 & 6.2 & 6.43 & 6.41 & 6.68 & 6.47 & 7.16 & 7.03 & 7.88 & 7.75 & 8.03 & 7.96 & 0.0358 & NS & NS \\
\hline & 90 & 6.25 & 6.16 & 6.39 & 6.37 & 6.64 & 6.43 & 7.12 & 6.99 & 7.84 & 7.71 & 7.99 & 7.92 & 0.0127 & 0.0357 & 0.0502 \\
\hline & 120 & 6.18 & 6.09 & 6.32 & 6.3 & 6.57 & 6.36 & 7.05 & 6.92 & 7.77 & 7.64 & 7.92 & 7.85 & 0.011 & 0.0308 & 0.0434 \\
\hline & 150 & 6.02 & 5.93 & 6.16 & 6.14 & 6.41 & 6.2 & 6.89 & 6.76 & 7.61 & 7.48 & 7.76 & 7.69 & 0.0098 & 0.0276 & 0.0388 \\
\hline & 180 & 5.94 & 5.85 & 6.08 & 6.06 & 6.33 & 6.12 & 6.81 & 6.68 & 7.53 & 7.4 & 7.68 & 7.61 & 0.0081 & 0.0227 & 0.032 \\
\hline \multicolumn{17}{|c|}{ Overall Acceptability } \\
\hline & 0 & 6.71 & 6.59 & 7.24 & 7.02 & 7.56 & 7.53 & 7.63 & 7.61 & 7.74 & 7.68 & 7.85 & 7.79 & 0.2367 & NS & NS \\
\hline & 30 & 6.04 & 5.95 & 6.18 & 6.16 & 6.43 & 6.22 & 6.91 & 6.78 & 7.63 & 7.5 & 7.78 & 7.71 & 0.056 & NS & NS \\
\hline & 60 & 5.97 & 5.88 & 6.11 & 6.09 & 6.36 & 6.15 & 6.84 & 6.71 & 7.56 & 7.43 & 7.71 & 7.64 & 0.0346 & 0.0973 & NS \\
\hline & 90 & 5.91 & 5.82 & 6.05 & 6.03 & 6.3 & 6.09 & 6.78 & 6.65 & 7.5 & 7.37 & 7.65 & 7.58 & 0.0121 & 0.0341 & 0.048 \\
\hline & 120 & 5.84 & 5.75 & 5.98 & 5.96 & 6.23 & 6.02 & 6.71 & 6.58 & 7.43 & 7.3 & 7.58 & 7.51 & 0.011 & 0.0308 & 0.0434 \\
\hline & 150 & 5.75 & 5.66 & 5.89 & 5.87 & 6.14 & 5.93 & 6.62 & 6.49 & 7.34 & 7.21 & 7.49 & 7.42 & 0.0098 & 0.0276 & 0.0388 \\
\hline & 180 & 5.66 & 5.57 & 5.8 & 5.78 & 6.05 & 5.84 & 6.53 & 6.4 & 7.25 & 7.12 & 7.4 & 7.33 & 0.0087 & 0.0243 & 0.0343 \\
\hline
\end{tabular}

Table 5: Effect of Storage Conditions, Preservative Levels and Packing Materials on Microbial (Yeast and Mold) Quality of Nagpur Mandarin Syrup Along with their Treatment Combinations. Count (No. $\left.\times 10^{6} \mathrm{cfu} / \mathrm{mL}\right)$

\begin{tabular}{|c|c|c|c|c|c|c|c|c|}
\hline \multirow{2}{*}{\multicolumn{2}{|c|}{$\begin{array}{c}\text { Tre. } \\
\text { Combination }\end{array}$}} & \multicolumn{7}{|c|}{ Storage Period/ Count Period } \\
\hline & & 0 Days & 30 Days & 60 Days & 90 Days & 120 Days & 150 Days & 180 Days \\
\hline TI & S1P1B1 & ND & ND & ND & ND & 1.39 & 1.42 & 1.46 \\
\hline T2 & S1P1B2 & ND & ND & ND & ND & 1.42 & 1.45 & 1.49 \\
\hline T3 & S1P2B1 & ND & ND & $\mathrm{ND}$ & ND & 1.28 & 1.31 & 1.35 \\
\hline T4 & S1P2B2 & ND & ND & $\mathrm{ND}$ & ND & 1.32 & 1.35 & 1.39 \\
\hline T5 & S1P3B1 & $\mathrm{ND}$ & ND & ND & ND & 1.21 & 1.24 & 1.28 \\
\hline T6 & S1P3B2 & ND & ND & $\mathrm{ND}$ & ND & 1.26 & 1.29 & 1.33 \\
\hline T7 & S2P1B1 & ND & ND & ND & ND & 1.15 & 1.18 & 1.22 \\
\hline T8 & S2P1B2 & ND & ND & ND & ND & 1.17 & 1.2 & 1.24 \\
\hline T9 & S2P2B1 & ND & ND & ND & ND & 1.07 & 1.1 & 1.14 \\
\hline T10 & S2P2B2 & ND & ND & ND & ND & ND & ND & 1.11 \\
\hline T11 & S2P3B1 & ND & ND & ND & ND & ND & ND & 1 \\
\hline T12 & S2P3B2 & ND & ND & ND & ND & ND & 1.02 & 1.05 \\
\hline
\end{tabular}

$\mathrm{ND}=$ not detected. 
Table 6: Cost of Preparation of Nagpur Mandarin Syrup

\begin{tabular}{|c|c|c|c|c|}
\hline Sr. No. & Particulars & Quantity & Rate (Rs.) & Cost (Rs.) \\
\hline \multicolumn{5}{|c|}{ I. Fixed Cost } \\
\hline 1. & $\begin{array}{l}\text { Interest @ } 12 \text { per cent on fixed assets of } 350 \mathrm{~kg} / \mathrm{hour} \\
\text { capacity screw type pulper is Rs } 68000 / \text { - (Rs } 8160 \text { for } 365 \\
\text { days i.e. Rs } 22.36 \text { per day). Working time } 8 \text { hours }\end{array}$ & & & 0.060 \\
\hline 2. & $\begin{array}{l}\text { Depreciation @ } 10 \text { per cent on fixed assets of } 350 \mathrm{~kg} / \mathrm{hour} \\
\text { capacity screw type pulper is Rs } 68000 / \text { - (Rs } 6800 \text { for } 365 \\
\text { days i.e. Rs } 18.63 \text { per day). Working time } 8 \text { hours }\end{array}$ & & & 0.050 \\
\hline \multicolumn{4}{|c|}{ Total } & 0.11 \\
\hline \multicolumn{5}{|c|}{ II. Variable Cost } \\
\hline 1. & $\begin{array}{l}\text { Nagpur mandarin fruit } \\
\text { ( } 4000 \mathrm{ml} \text { juice) }\end{array}$ & $7.600 \mathrm{~kg}$ & $\begin{array}{l}30.00 \text { per } \\
\mathrm{kg}\end{array}$ & 228.00 \\
\hline 2. & Sugar & 08.201 & $30.00 / \mathrm{kg}$ & 246.03 \\
\hline 3. & Citric acid & $0.118 \mathrm{~kg}$ & $120.00 / \mathrm{kg}$ & 14.46 \\
\hline 4. & Water charges & 3.68 liter & $1.00 /$ liter & 3.68 \\
\hline 5. & Preservative & $5.6 \mathrm{~g}$ & $1000 / \mathrm{kg}$ & 5.60 \\
\hline 6. & Glass bottle $(650 \mathrm{ml})$ & 24 & 12.00 & 288.00 \\
\hline 7. & Crown cork & 24 & 0.60 & 14.40 \\
\hline \multicolumn{4}{|c|}{ Total } & 800.17 \\
\hline 8. & $\begin{array}{l}\text { Overhead charges (@ } 10 \% \text { ) including Labor, Electricity } \\
\text { charges, Pasteurization cost ( Gas) }\end{array}$ & & & 80.02 \\
\hline \multicolumn{4}{|c|}{ 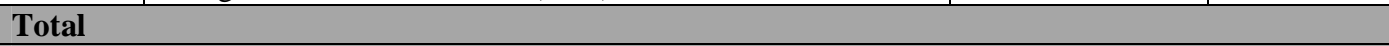 } & 880.19 \\
\hline \multicolumn{4}{|c|}{ Grand Total of 16 lit } & 880.30 \\
\hline & Total Cost of 1 lit Syrup (Fixed Cost + Variable Cost) & & & 55.02 \\
\hline
\end{tabular}


